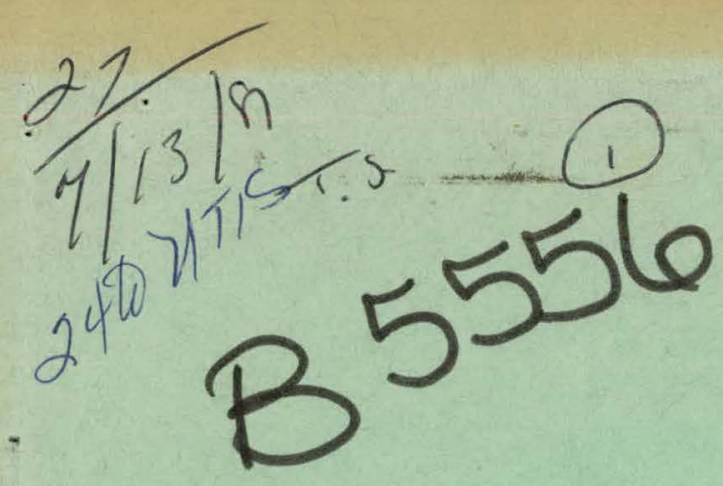

UCID- 19048

\title{
SPECIFICATIONS FOR THE \\ LINEAR CHARGE COUPLED DEVICE FOR USE IN TRANSIENT RECORDING
}

Joseph W. Balch

May 28,1981

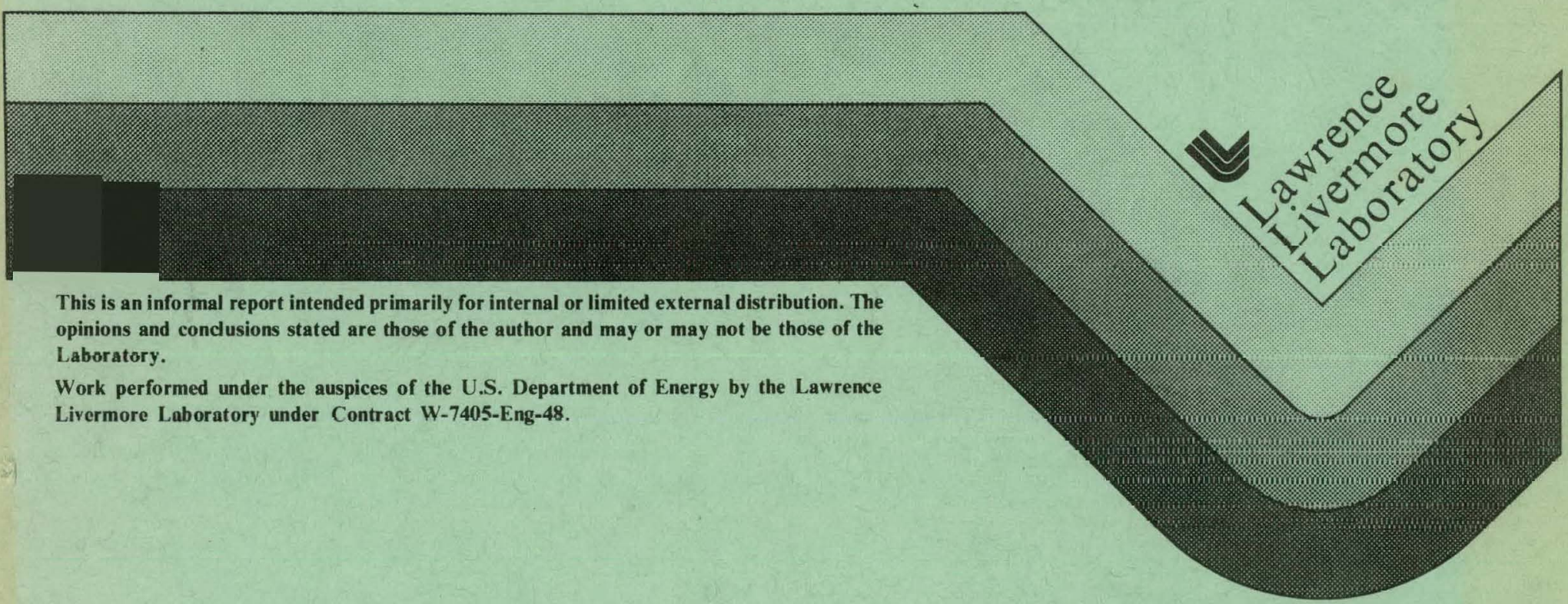




\section{DISCLAIMER}

This report was prepared as an account of work sponsored by an agency of the United States Government. Neither the United States Government nor any agency Thereof, nor any of their employees, makes any warranty, express or implied, or assumes any legal liability or responsibility for the accuracy, completeness, or usefulness of any information, apparatus, product, or process disclosed, or represents that its use would not infringe privately owned rights. Reference herein to any specific commercial product, process, or service by trade name, trademark, manufacturer, or otherwise does not necessarily constitute or imply its endorsement, recommendation, or favoring by the United States Government or any agency thereof. The views and opinions of authors expressed herein do not necessarily state or reflect those of the United States Government or any agency thereof. 


\section{DISCLAIMER}

Portions of this document may be illegible in electronic image products. Images are produced from the best available original document. 


\section{PAGES $\mathrm{i}$ to $\mathrm{ii}$ WERE INTENTIONALLY LEFT BLANK}




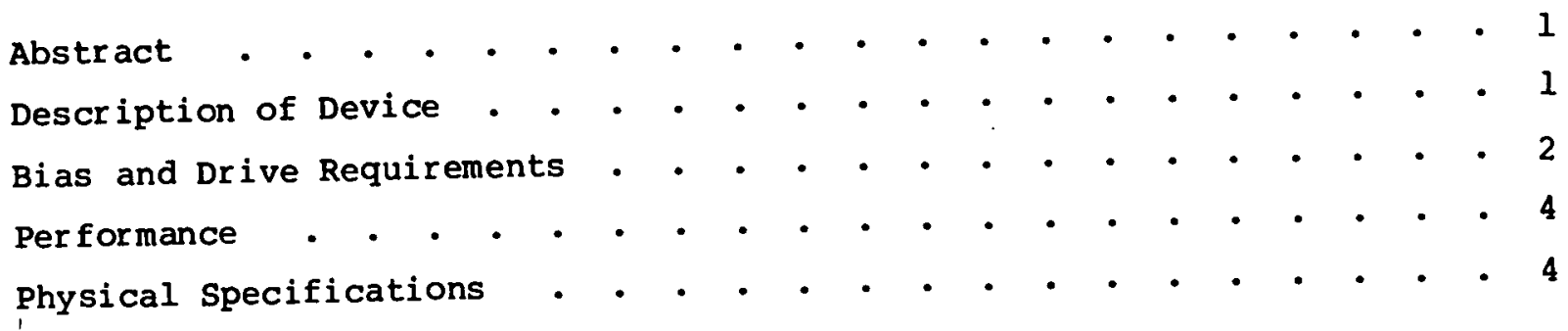

Physical specifications

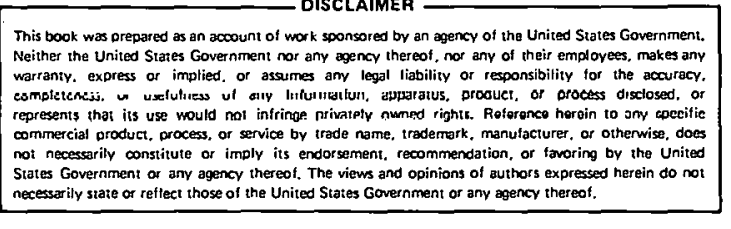

ii i 


\title{
SPECIFICATIONS FOR THE \\ LINEAR CHARGE COUPLED DEVICE \\ FOR USE IN TRANSIENT RECORDING
}

Joseph W. Balch

\begin{abstract}
Specifications are presented for the Linear Charge Coupled Device (LCCD) developed at the Lawrence Livermore National Laboratory for recording data from transients. This device can be used to record electrical signals at sample rates greater than $10^{9}$ samples per second. Both electrical and physical specifications of the device are presented. The bias and drive requirements of the device are presented in tables and in timing diagrams. Typical performance data are tabulated and shown in oscilloscope photos. The physical specifications of the device include plane and cross sectional drawings of its various registers and I/O sections. Enlarged photos of the mask set are shown and all critical dimensions of the active regions are given. Finally, the impurity doping profile used for the transfer channels is shown.
\end{abstract}

DESCRIPTION OF DEVICE

The LCCD is a Linear Charge Coupled Device type of analog delay line developed for recording high speed transients. Its architecture and design permit transient recording at sample rates of more than $10^{9}$ samples per second. In typical recording of transients, data are loaded into the 640 analog storage cells of the ICCD at a high clock rate. Thermally generated 
currents that fill the storage wells with random charge limit the total storage time of the samples in the LCCD to less than 100 milliseconds. Later, the data are read out of the cells at a much slower rate (e.g., $100 \mathrm{kHz}$ ) for additional processing by an $A / D$ converter or oscilloscope.

The LCCD consists of five identical input registers, each having 132 storage cells. A schematic of the LCCD is shown in Fig. 1. There is a separate input signal gate for each input register, but all five input structures share a common sample-gate clock. Thus, the LCCD simultaneously samples five separate input signals. The maximum sample rate of each channel is greater than $250 \times 10^{6}$ samples per second. To achieve rates of $10^{9}$ samples per second for a single input signal, the device is used with an off-chip signal splitter and five incremental delay lines to simultaneously sample five delayed replicas of the input signal. By this approach, the LCCD achieves an aggregate sample rate of $1.25 \times 10^{9}$ samples per second when the clock rate is $250 \mathrm{MHz}$.

The analog data recorded in the device are read out through a single output terminal. The device contains an on-chip multiplexer that recombines the five parallel streams of input data into a single output data stream. The output signal is obtained from an NMOs transistor that is used as a source follower with an off-chip load. Charge detection is done on-chip using a precharged diode connected to the gate of the output transistor. The output structure of the LCCD is designed for low speed operations only, and output data rates are typically $50 \mathrm{kHz}$ to $300 \mathrm{kHz}$.

LCCDs are packaged in a 40-pin flat pack designed for high bandwidth applications. Figure 2 shows the package and Table 1 lists the pin-out nomenclature.

\section{BIAS AND DRIVE REQUIREMENTS}

The normal dc voltages for the LCCD, listed in Table 2, are given with respect to a substrate ground. The dc current requirements for the device are very small. Terminals connected to floating electrodes (ISG, OTG, TG) require less than $1 \mathrm{nA}$ of current, and those connected to reversed biased diodes. (ISM, NM, CHS, SK) require less than $20 \mu \mathrm{A}$. The five input diffusions (IDI through ID5) are reversed biased diodes, but they also provide the electron 
charge packets that move down the transfer channels. Their current requirements are typically 10-50 $\mathrm{AA}$. The drain terminal (OD) of the output transistor requires approximately $1 \mathrm{~mA}$ of current. To reduce signal distortion and unwanted parasitic noises on the output signal, all dc biased terminals should have by-pass capacitors located near the device, and they should be biased from low impedance sources.

The drive requirements for the several clocks required to operate the LCCD are given in Table 3. The clocks are:

1. A sampling clock $\left(\phi_{\mathrm{CG}}\right)$ applied to the five input structures of the device.

2. A two-phase or four-phase clock to transfer charge in the five input registers.

3. A transfer clock $\left(\phi_{P S G}\right)$ to control charge transfer from the five input registers to the single output register.

4. A two-phase or four-phase clock to transfer charge in the output register.

5. A reset clock to precharge the detection diode of the output structure.

6. A clock to drive the buffer gate electrode of the input structures. This terminal may be driven either by a separate clock ( $\left.\phi_{B G}\right)$ or by phase one of the input register clocks (listed as item 2 above). Better input sampling is obtained if the buffer gate clock is a separate clock, with voltage levels independent of the transfer clocks of the input registers.

The load capacitances of the clock electrodes are given in Table 4. Load capacitances are nonlinear functions of the voltages across the capacitances because voltage dependent depletion regions exist at the silicon surface and in the $\mathrm{P}-\mathrm{N}$ junctions of the device. The minimum and maximum ranges of the capacitances listed in Table 4 correspond to the minimum and maximum voltages of the applied clocks.

The recommended timing diagrams for the clocks are shown in Fig. 3 for the input registers and in Fig. 4 for the output register. Each storage cell of both the input registers and the output register consists of four adjacent electrodes connected to four separate clock bus lines. The registers can be operated by either four-phase or two-phase clocks. For four-phase clocks, each clock phase should have a 508 duty cycle, and the four clocks should have quadrature phasing with respect to each other. The timing diagram shown in Fig. 4 for the output register demonstrates quadrature phasing. 
To operate a shift register with two-phase clocks, the four clock-bus lines of a register are driven in pairs by two clock phases that are $180^{\circ}$ out of phase. In addition, a dc bias must be applied between the two electrodes of a given clock phase to create unidirectional flow of charge in the register. Figure 3 demonstrates two-phase clocks for the five input registers.

At the end of the high speed recording interval, the clocks of the input register must switch from their high recording frequency to a much slower readout frequency. This frequency reduction must be done in such a way that the charge samples in adjacent shift register stages remain distinct. In a two-phase clocking scheme, switching requires that one clock phase remains high and the other clock phase remains low throughout the frequency switch-down interval.

PERFORMANCE

The performance of the device is outlined in Table 5 . Figure 5 shows a typical pulse response for one of the five input registers when the device is driven by a $200 \mathrm{MHz}$, two-phase clock. In this photo an output signal of 200 $\mathrm{mV}$ is shown for an input signal of $1.5 \mathrm{~V}$. For this photo the device was biased for a bipolar input signal by biasing the input diffusions so that they injected one-half full-well charge packets (200 $\mathrm{mV}$ output) into the transfer registers when the input signal was zero:

PHYSICAL SPECIFICATIONS

The overall geometry of the LCCD is shown in the photo of Fig. 6. The device consists of four sections:

1. Five input structures.

2. Five input registers.

3. One output register.

4. A charge detection FET. 
The physical layout for the input structures and the high speed transfer registers is shown in Fig. 7. This composite scale drawing shows all the electrodes (BG, IN, ISG, CG) and diffusions (IDI through ID5) of the five input structures, and transfer electrodes for the input registers $\phi_{\text {IIB' }}$ $\phi_{\text {IIS' }} \phi_{\text {I2B' }}$ and $\phi_{\text {I2S }}$. The physical dimensions for the various electrodes are listed in Table 6 . The minimum feature size on the device is $5 \mu$, which is the size of the isolation gate and the transfer electrodes of the input registers.

A cross sectional view of an input structure and the first transfer stage is shown in Fig. 8. The registers are built using buried channel $\mathrm{CCD}$ technology, which uses a surface N-layer on a P-type substrate. The $1200 \mathrm{~A}$ dielectric that separates the silicon surface from the polysilicon electrodes consists of $800 \mathrm{~A}$ of silicon dioxide and $400 \mathrm{~A}$ of silicon nitride. Three levels of polysilicon are used for the various electrodes on the device. The doping profile of the $\mathrm{N}$-layer is shown in Fig. 9.

The top and side views of the charge detection FET of the LCCD are shown in Figs. 10 and 11. The active region of the output transistor is an area of the P-type substrate having no ion implantations. However, the output transfer register uses the same N-P doping profile as the input registers. The active dielectric of the output register and output FET also consists of $800 \mathrm{~A}$ of silicon dioxide and $400 \mathrm{~A}$ of silicon nitride. The mask set used to fabricate the device contains 12 separate masks. Table 7 1ists the mask set. Copies of the masks are shown in Figs. 12 to 23 at a magnification of approximately 50 times. 
TABLE 1. Pin assignment for an LCCD having 2-Phase input registers.

\begin{tabular}{|c|c|c|}
\hline Pin No. & Symbol & Name \\
\hline 1 & ID3 & Input diffusion 3 \\
\hline 2 & ID4 & Input diffusion 4 \\
\hline 3 & IN 4 & Signal input 4 \\
\hline 4 & SUB & Substrate \\
\hline 5 & ID5 & Input diffusion 5 \\
\hline 6 & IN5 & Signal input 5 \\
\hline 7 & CHS & Channel stop \\
\hline 8 & BG & Buffer gate \\
\hline 9 & $\varnothing \mathrm{I} \perp \mathrm{B}$ & Input register clock $\varnothing 1$, block \\
\hline 10 & $\emptyset I 1 B$ & Input register clock $\emptyset 1$, block \\
\hline 11 & $\varnothing \mathrm{I} I \mathrm{~S}$ & Input register clock $\emptyset 1$, storage \\
\hline 12 & $\emptyset \mathrm{IIS}$ & Input register clock $\emptyset 1$, storage \\
\hline 13 & OPSG & Parallel-serial transfer gate \\
\hline 14 & SUB & Substrate \\
\hline 15 & $\varnothing 04$ & Output register clock $\varnothing 4$ \\
\hline 16 & $\varnothing 02$ & Output register clock $\emptyset 2_{2}$ \\
\hline 17 & $\varnothing 03$ & Output register clock $\emptyset 3$ \\
\hline 18 & $\varnothing 01$ & Output register clock $\emptyset_{1}$ \\
\hline 19 & NM & N-Moat \\
\hline 20 & SUB & Substrate \\
\hline 21 & OUT & Output signal \\
\hline 22 & OD & Output FET drain \\
\hline 23 & SR & Sink \\
\hline 24 & RG & Reset gate \\
\hline 25 & TG & Tetrode gate \\
\hline 26 & OTG & Output transfer gate \\
\hline 27 & SUB & Substrate \\
\hline 28 & øI2S & Input register clock $\phi 2$, storage \\
\hline 29 & $\emptyset 12 s$ & Input register clock $\varnothing 2$, storage \\
\hline 30 & ØI2B & Input register clock $\varnothing 2$, block \\
\hline 31 & $\emptyset I 2 B$ & Input register clock $\varnothing 2$, block \\
\hline
\end{tabular}


TABLE 1. (Continued) .

\begin{tabular}{lll}
\hline Pin No. & Symbol & \multicolumn{1}{c}{ Name } \\
\hline 32 & ISM & Isolation moat \\
33 & ICG & Cutter gate \\
34 & ISG & Isolation gate \\
35 & IN1 & Signal input 1 \\
36 & ID1 & Input diffusion 1 \\
37 & SUB & Substrate \\
38 & IN2 & Signal input 2 \\
39 & ID2 & Input diffusion 2 \\
40 & IN3 & Input signal 3 \\
\hline
\end{tabular}


TABLE 2. Bias voltage requirements.

\begin{tabular}{|c|c|c|c|c|}
\hline \multirow[b]{2}{*}{ Symbol } & \multirow[b]{2}{*}{ Characteristic } & \multicolumn{3}{|c|}{ Range of Voltage (V) } \\
\hline & & Min & $v_{\text {SUB }}=$ & $\operatorname{Max}$ \\
\hline $\mathrm{v}_{\text {ID }}$ & Input diffusion voltage & 6 & 13 & 20 \\
\hline $\mathrm{V}_{\text {ISG }}$ & Isolation gate voltage & -5 & +2 & +5 \\
\hline $\mathrm{v}_{\text {OTG }}$ & Output transfer gate voltage & -5 & -2.5 & +5 \\
\hline $\mathbf{v}_{\text {SK }}$ & Output sink voltage & 10 & 16 & 25 \\
\hline TG & $\begin{array}{l}\text { Tetrode gate voltage } \\
\text { (Reset FET) }\end{array}$ & -5 & $\varnothing$ & +5 \\
\hline $\mathrm{v}_{\mathrm{OD}}$ & Output FET drain supply & 15 & 20 & 25 \\
\hline $\mathrm{v}_{\text {CHS }}$ & Channel stop voltage & $\varnothing$ & $\varnothing$ & -5 \\
\hline $\mathrm{v}_{\mathrm{NM}}$ & $\mathrm{N}$-moat voltage & $\emptyset$ & $\varnothing$ & 5 \\
\hline $\mathrm{V}_{\text {ISM }}$ & Isolation moat & $\phi$ & $\varnothing$ & -5 \\
\hline
\end{tabular}


TABLE 3. Clock drive requirements.

\begin{tabular}{|c|c|c|c|c|}
\hline \multirow[b]{2}{*}{ Symbol } & \multirow[b]{2}{*}{ Characteristic } & \multicolumn{3}{|c|}{ Range of Voltage (V) } \\
\hline & & Min & Typ & Max \\
\hline \multirow[t]{2}{*}{$v_{\emptyset I S L}$} & $\begin{array}{l}\text { Input register } \\
\text { storage electrode }\end{array}$ & & & \\
\hline & $2 \varnothing$ clocks low & -10 & -5 & - \\
\hline$v_{. \varnothing I S H}$ & $\begin{array}{l}\text { Input register } \\
\text { storage electrode }\end{array}$ & & & \\
\hline & $2 \varnothing$ clocks high & - & 5 & 10 \\
\hline$v_{\varnothing I B L}$ & $\begin{array}{l}\text { Input register } \\
\text { blocking electrode }\end{array}$ & & & \\
\hline & $2 \varnothing$ clocks low & -15 & -10 & - \\
\hline$v_{\emptyset I B H}$ & $\begin{array}{l}\text { Input register } \\
\text { blocking electrode } \\
2 \emptyset \text { clocks high }\end{array}$ & -- & 0 & 5 \\
\hline$v_{\emptyset P S G L}$ & $\begin{array}{l}\text { Parallel to serial } \\
\text { transfer gate } \\
\text { clock low }\end{array}$ & -15 & -9 & -- \\
\hline$v_{\emptyset \mathrm{PSGH}}$ & $\begin{array}{l}\text { Parallel to serial } \\
\text { transfer gate. }\end{array}$ & & & \\
\hline & clock high & +10 & +15 & -- \\
\hline$v_{\varnothing O L}$ & $\begin{array}{l}\text { Output register } \\
4 \varnothing \text { clocks low }\end{array}$ & -10 & -3 & -- \\
\hline$v_{\varnothing O H}$ & $\begin{array}{l}\text { Output register } \\
4 \emptyset \text { clocks high }\end{array}$ & -- & +10 & +15 \\
\hline $\mathrm{v}_{\text {CGL }}$ & $\begin{array}{l}\text { Cutter gate } \\
\text { clock low }\end{array}$ & -5 & -3 & -- \\
\hline $\mathrm{v}_{\mathrm{CGH}}$ & $\begin{array}{l}\text { Cutter gate } \\
\text { clook high }\end{array}$ & -- & +1.2 & +15 \\
\hline$v_{\text {ØBGL }}$ & $\begin{array}{l}\text { Buffer gate } \\
\text { clock low }\end{array}$ & -5 & -3 & -- \\
\hline$v_{\emptyset B G H}$ & $\begin{array}{l}\text { Buffer gate } \\
\text { clock high }\end{array}$ & -- & +12 & +15 \\
\hline$v_{\emptyset \text { QRGL }}$ & $\begin{array}{l}\text { Reset gate } \\
\text { clock low }\end{array}$ & -5 & -3 & -- \\
\hline$v_{\emptyset \text { RGH }}$ & $\begin{array}{l}\text { Rceet gate } \\
\text { clock high }\end{array}$ & - & 0 & +5 \\
\hline
\end{tabular}


TABLE 4. Load capacitances of clock electrodes.

\begin{tabular}{|c|c|c|c|c|c|}
\hline \multirow[b]{2}{*}{ Symbol } & \multirow[b]{2}{*}{ Characteristic } & \multicolumn{3}{|c|}{ Range } & \multirow[b]{2}{*}{ Units } \\
\hline & & Min & TYP & $\operatorname{Max}$ & \\
\hline$c_{\varnothing I i}$ & $\begin{array}{l}\text { Two-phase clock } \\
\text { capacitance to } \\
\text { substrate of } \\
\text { input registers } \\
(i-1,2)\end{array}$ & 12 & -- & 40 & $\mathrm{pf}^{\mathrm{a}}$ \\
\hline$c_{\emptyset I l, 2}$ & $\begin{array}{l}\text { Input register } \\
\text { inter-phase } \\
\text { clock capacitance }\end{array}$ & 6 & -- & 14 & $p f^{a}$ \\
\hline $\mathrm{c}_{\mathrm{CG}}$ & $\begin{array}{l}\text { Cutter gate capacitance } \\
\text { to substrate }\end{array}$ & 1 & 1.5 & 2 & $\mathrm{pf}^{\mathrm{a}}$ \\
\hline $\mathrm{C}_{\mathrm{CG}, \mathrm{IN}}$ & $\begin{array}{l}\text { Cutter gate capacitance } \\
\text { to input signal } \\
\text { electrode }\end{array}$ & 0.2 & -- & 0.35 & $\mathrm{pf}^{\mathrm{a}}$ \\
\hline $\mathrm{C}_{\mathrm{CG}, \mathrm{ISG}}$ & $\begin{array}{l}\text { Cutter gate capacitance } \\
\text { to isolation gate }\end{array}$ & 0.06 & -- & 0.14 & $\mathrm{pf}^{\mathrm{a}}$ \\
\hline $\mathrm{c}_{\text {IN }}$ & $\begin{array}{l}\text { Input signal gate } \\
\text { capacitance to substrate }\end{array}$ & 1 & 1.3 & 2 & $\mathrm{pf}$ \\
\hline $\mathrm{C}_{\text {IN, BG }}$ & $\begin{array}{l}\text { Signal gate capacitance } \\
\text { to buffer gate }\end{array}$ & 0.01 & -- & 0.025 & $\mathrm{pf}^{\mathrm{a}}$ \\
\hline$c_{B G}$ & $\begin{array}{l}\text { Buffer gate capacitance } \\
\text { to substrate }\end{array}$ & 1 & 1.5 & 2 & $\mathrm{pf}$ \\
\hline$c_{B G, \emptyset I 2}$ & $\begin{array}{l}\text { Buffer gate capacitance } \\
\text { to } \varnothing \mathrm{I} 2 \text { phase }\end{array}$ & 0.06 & -- & 0.14 & $p f^{a}$ \\
\hline$c_{\varnothing 0 i}$ & $\begin{array}{l}\text { Output register phase } \\
\text { capacitance to substrate } \\
(i=1,2,3,4)\end{array}$ & 2 & -- & 6 & $\mathrm{pf}$ \\
\hline$c_{\varnothing 0 i, j}$ & $\begin{array}{l}\text { Output register inter- } \\
\text { phase clock capacitance }\end{array}$ & 0.5 & -- & 2.0 & $\mathrm{pf}$ \\
\hline
\end{tabular}


TABLE 5. LCCD typical performance.

\begin{tabular}{|c|c|c|c|c|}
\hline Par ameter & Value & Units & Condition & $\begin{array}{l}\text { Ref. } \\
\text { Fig. }\end{array}$ \\
\hline $\begin{array}{l}\text { Charge transfer } \\
\text { efficiency }\end{array}$ & 0.9996 & $\begin{array}{l}\text { Per S-R } \\
\text { stage }\end{array}$ & $\begin{array}{l}\text { Fat zero }=200 \mathrm{mV} \\
\text { Signal }=200 \mathrm{mV} \\
\mathrm{f}=200 \mathrm{MHz}, 2 \varnothing, \\
1 \mathrm{in}^{\mathrm{p}}=\mathrm{p}-\mathrm{p}\end{array}$ & 5 \\
\hline & & & & \\
\hline Thermal generation & $<1$ & $\mathrm{mV} / \mathrm{ms}$ & $\begin{array}{l}\text { Fat zero }=\varnothing \\
\text { f }_{\text {out }}=20 \mathrm{kHz}\end{array}$ & -- \\
\hline $\begin{array}{l}\text { Full well output } \\
\text { signal }\end{array}$ & 400 & $\mathrm{mV}$ & $\begin{array}{l}\mathrm{f}_{\text {in }}=200 \mathrm{MHz}, 2 \varnothing \\
\mathrm{f}_{\text {out }}=200 \mathrm{kHz}, 4 \varnothing\end{array}$ & 5 \\
\hline $\begin{array}{l}\text { Full well input } \\
\text { signal }\end{array}$ & 3.0 & $\mathrm{~V}$ & $E_{\text {in }}=200 \mathrm{MHz}, 2 \varnothing$ & 5 \\
\hline $\begin{array}{l}\text { Maximum high speed } \\
\text { clock frequency }\end{array}$ & 250 & $\mathbf{M H z}$ & -- & -- \\
\hline $\begin{array}{l}\text { Transconductance } \\
\text { of output FET }\end{array}$ & 0.125 & mmho & -- & -- \\
\hline $\begin{array}{l}\text { Saturation } \\
\text { drain conductance } \\
\text { of output FET }\end{array}$ & 8 & umho & -- & - \\
\hline
\end{tabular}


TABLE 6. Dimensions of LCCD components .

\begin{tabular}{|c|c|c|c|}
\hline Physical dimensions (Active areas) & $\begin{array}{c}\text { Nominal } \\
\text { device dimension }\end{array}$ & Toler ance & Units \\
\hline Gate length, isolation gate & 5.0 & \pm 1.5 & $\mu$ \\
\hline Gate length, cutter gate & 7.0 & \pm 1.5 & $\mu$ \\
\hline Gate length, signal gate & 6.0 & \pm 1.5 & $\mu$ \\
\hline Gate length, buffer gate & 7.0 & \pm 1.5 & $\mu$ \\
\hline Gate length, clock phase ØIlB & 7.0 & \pm 1.5 & $\mu$ \\
\hline Gate length, clock phase $\varnothing \mathrm{I}$ IS & 5.0 & \pm 1.5 & $\mu$ \\
\hline Gate length, clock phase $\varnothing \mathrm{I} 2 \mathrm{~B}$ & 7.0 & \pm 1.5 & $\mu$ \\
\hline Gate length, clock phase $\emptyset$ I $2 S$ & 5.0 & \pm 1.5 & $\mu$ \\
\hline Channel width, input registers & 16.0 & \pm 2.0 & $\mu$ \\
\hline Channel width, output registers & 26.0 & \pm 2.0 & $\mu$ \\
\hline $\begin{array}{l}\text { Gate length, parallel - serial } \\
\text { transfer gate }\end{array}$ & 9.5 & \pm 1.5 & $\mu$ \\
\hline Gate length, clock phase $\varnothing 01$ & 7.5 & \pm 1.5 & $\mu$ \\
\hline Gate length, clock phase $ø 02$ & 9.5 & \pm 1.5 & $\mu$ \\
\hline Gate length, clock phase $103^{-}$ & 7.5 & \pm 1.5 & $\mu$ \\
\hline Gate length, clock phase $\varnothing 04$ & 9.5 & \pm 1.5 & $\mu$ \\
\hline Gate length, output gate & 7.5 & \pm 1.5 & $\mu$ \\
\hline Gate length, tetrode gate & 7.5 & \pm 1.5 & $\mu$ \\
\hline Gate length, reset gate & 8.5 & \pm 1.5 & $\mu$ \\
\hline Gate length, output FET & 10.0 & \pm 1.5 & $\mu$ \\
\hline Gate width, output FET & 21.5 & \pm 1.5 & $\mu$ \\
\hline Thin channel dielectric thickness & 1200 & \pm 100 & A \\
\hline $\begin{array}{l}\text { Isolation dielectric thickness } \\
\text { between polysilicon electrodes }\end{array}$ & 3000 & \pm 300 & A \\
\hline Field dielectric thickness & 15,000 & \pm 1500 & A \\
\hline Polysilicon thickness & 6000 & \pm 1500 & A \\
\hline
\end{tabular}


TABLE 7. Mask set used for LCCD.

\begin{tabular}{lll}
\hline Mask & Shown in & \multicolumn{1}{c}{ Function } \\
\hline LCCD- 1 & Fig. 12 & N-Channel implant mask \\
LCCD- 2 & Fig. 13 & Channel stop mask \\
LCCD- 3 & Fig. 14 & N-Moat mask \\
LCCD- 4 & Fig. 15 & Channel window mask \\
LCCD- 5 & Fig. 16 & Channel nitride mask \\
LCCD- 6 & Fig. 17 & 1st polysilicon mask \\
LCCD- 7 & Fig. 18 & 2nd polysilicon mask \\
LCCD-10 & Fig. 19 & 3rd polysilicon mask \\
LCCD-11 & Fig. 20 & N+ I/O diffusion mask \\
LCCD-12 & Fig. 21 & Contact window mask \\
LCCD-13 & Fig. 22 & Metal mask \\
LCCD-14 & Fig. 23 & Bond pad window mask \\
\hline
\end{tabular}




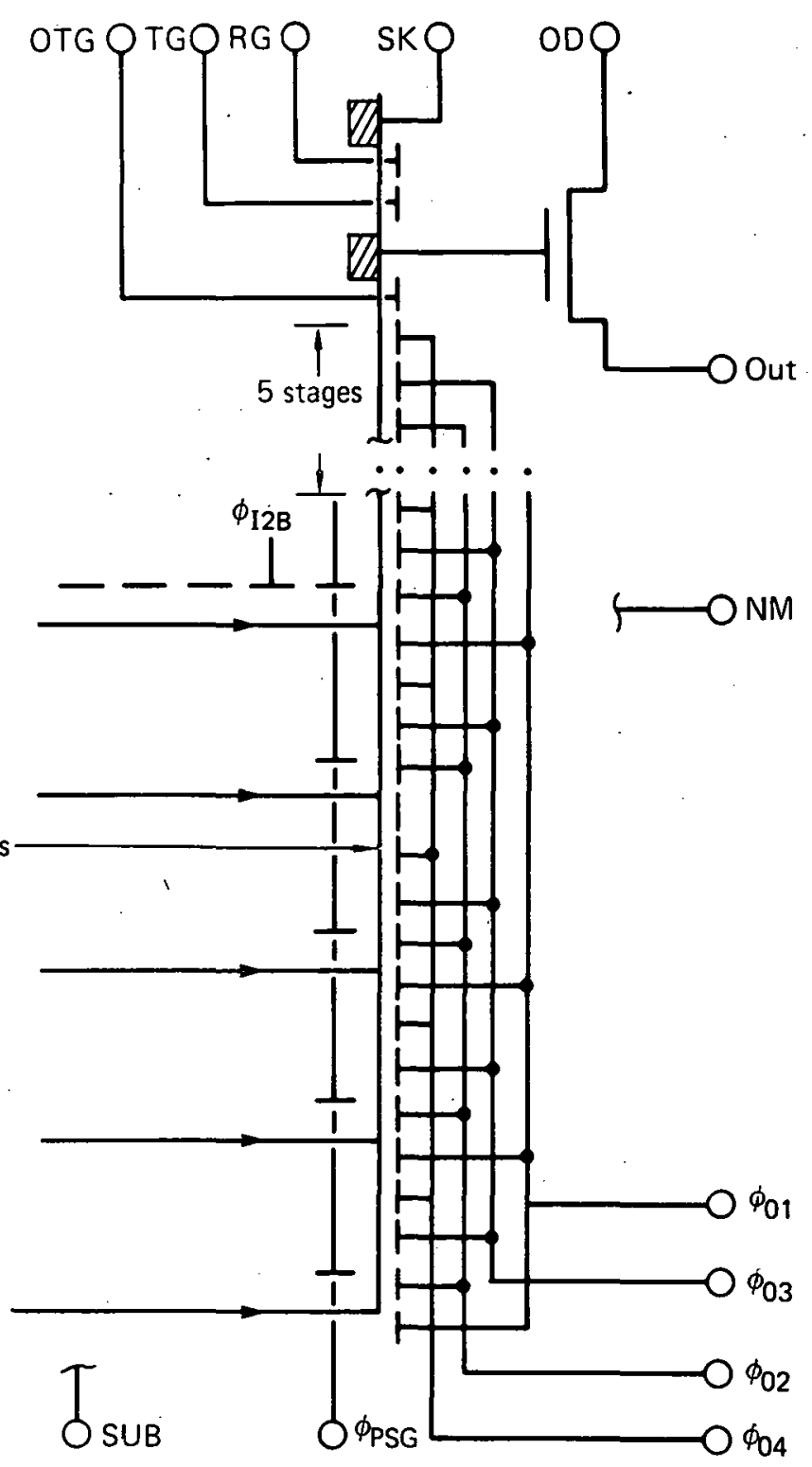

FIG. 1. Schematic of LCCD. 


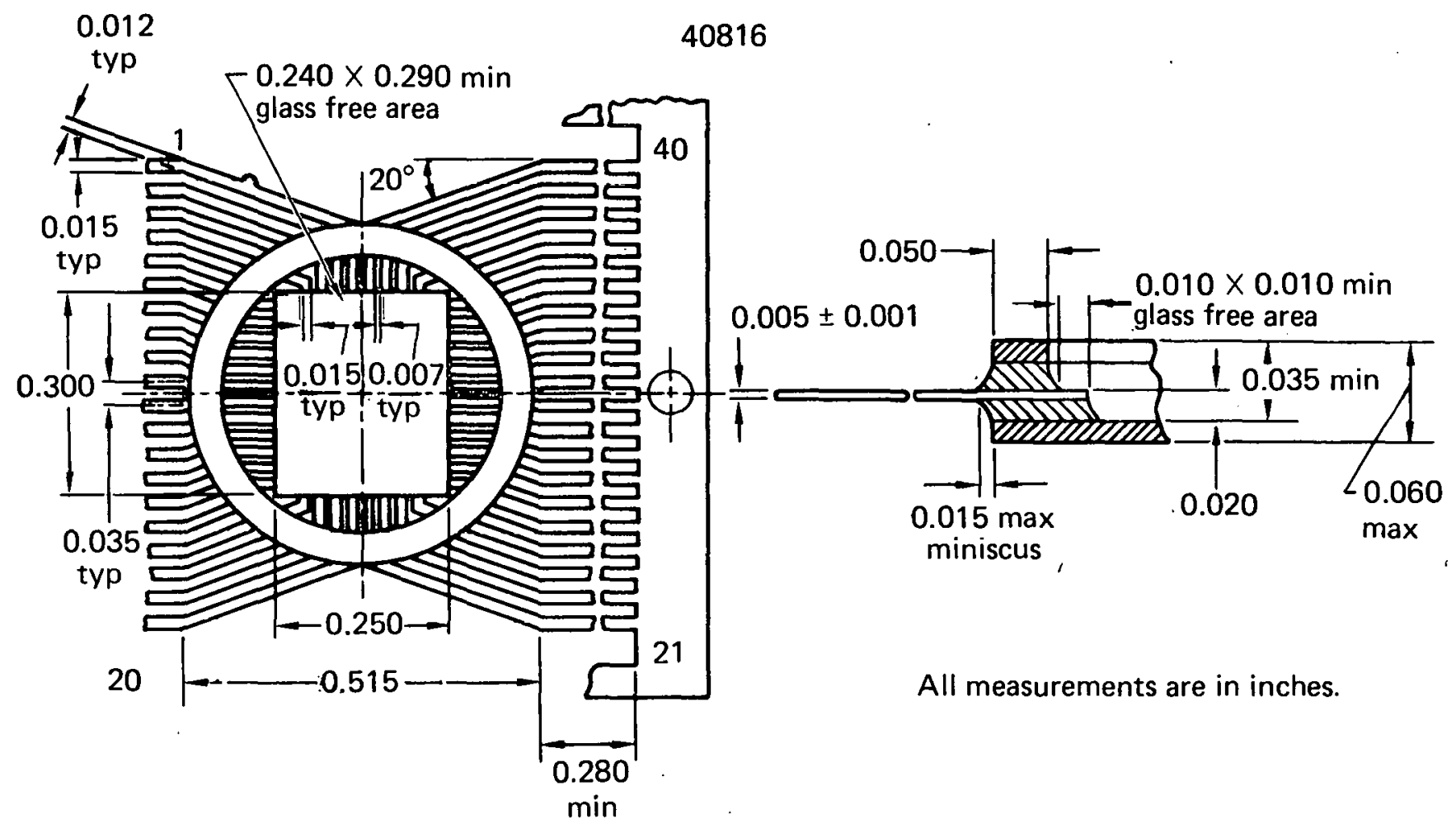

FIG. 2. Forty pin flat-pack used to package the LCCD. 


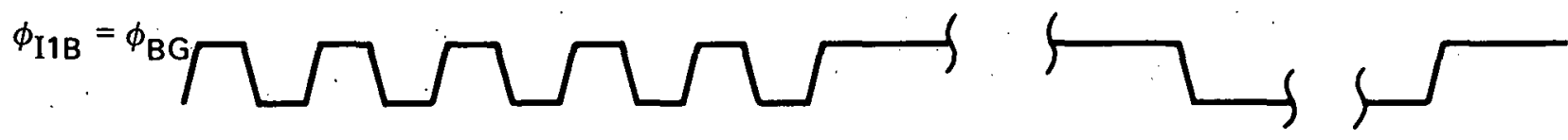

$\phi_{\mathrm{I} 1 \mathrm{~S}} \quad$ Same timing diagram as $\phi_{\mathrm{I} 1 \mathrm{~B}}$, except $+5 \mathrm{~V}$ offset.

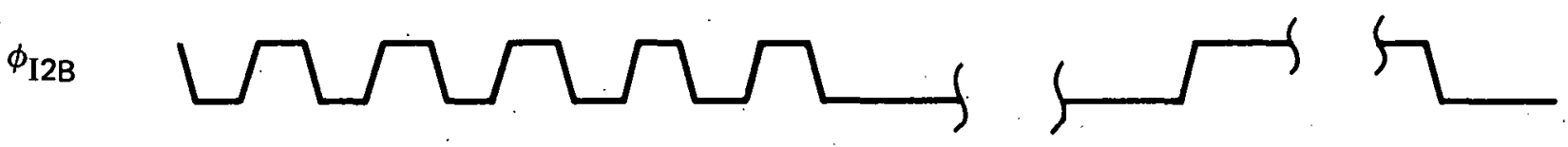

$\phi_{\mathrm{I} 2 \mathrm{~S}} \quad$ Same timing diagram as $\phi_{\mathrm{I} 2 \mathrm{~B}}$, except $+5 \mathrm{~V}$ offset.

$\phi_{\mathrm{PSG}}$

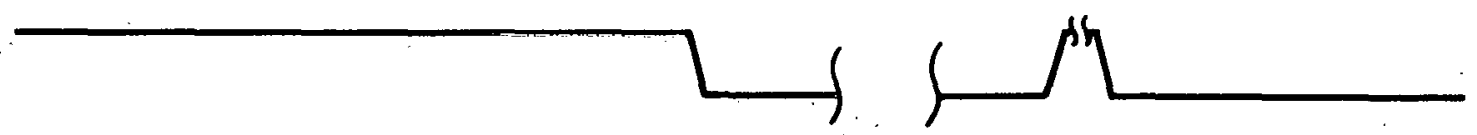

$\phi_{\mathrm{CG}}$

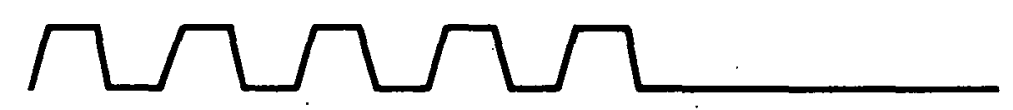

FIG. 3. Input timing using two-phase clocks. 


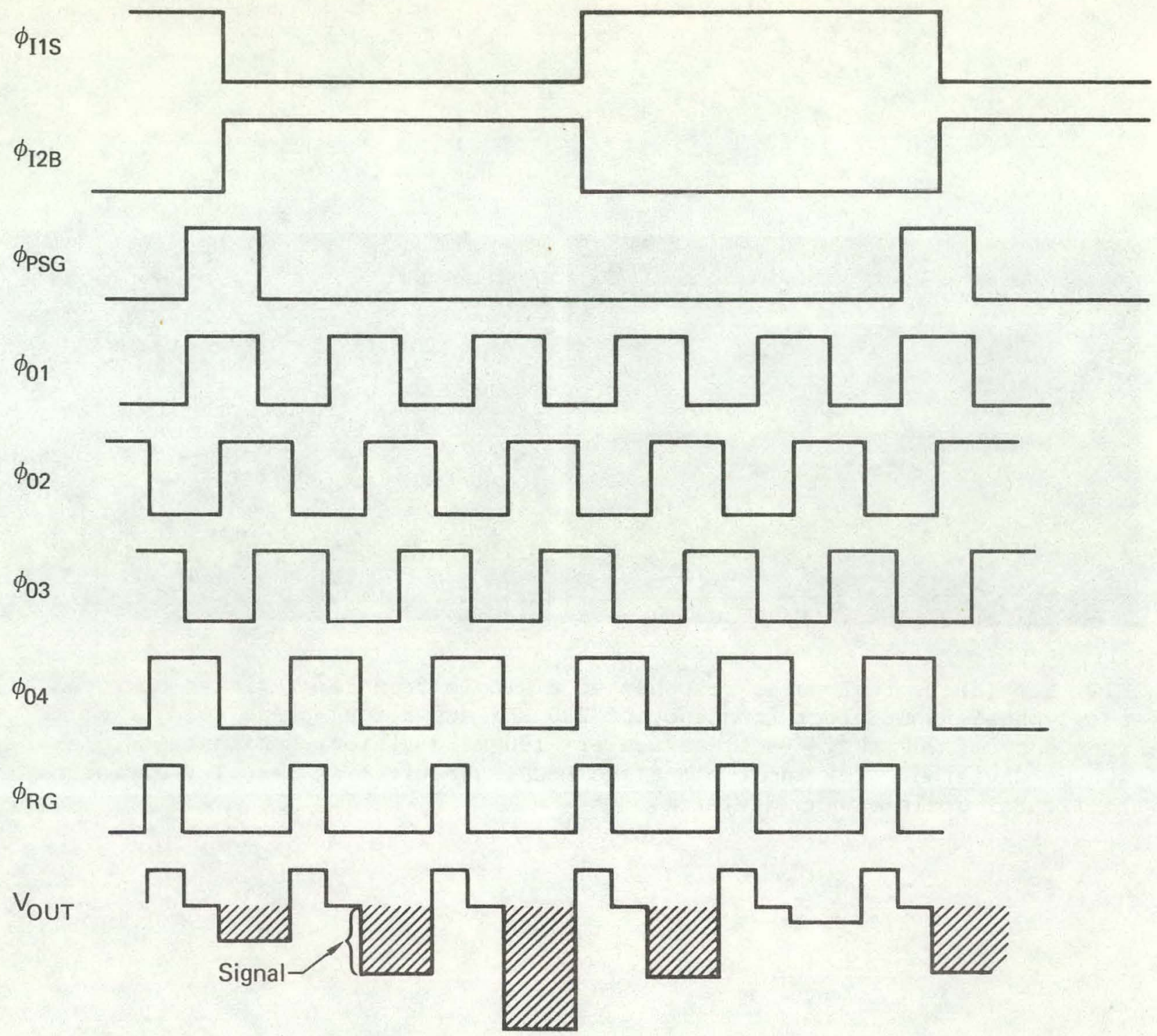

Note: The vertical clocks should run continuously to avoid any transients in output waveform at switchdown.

FIG. 4. Readout timing using four-phase clocks. 


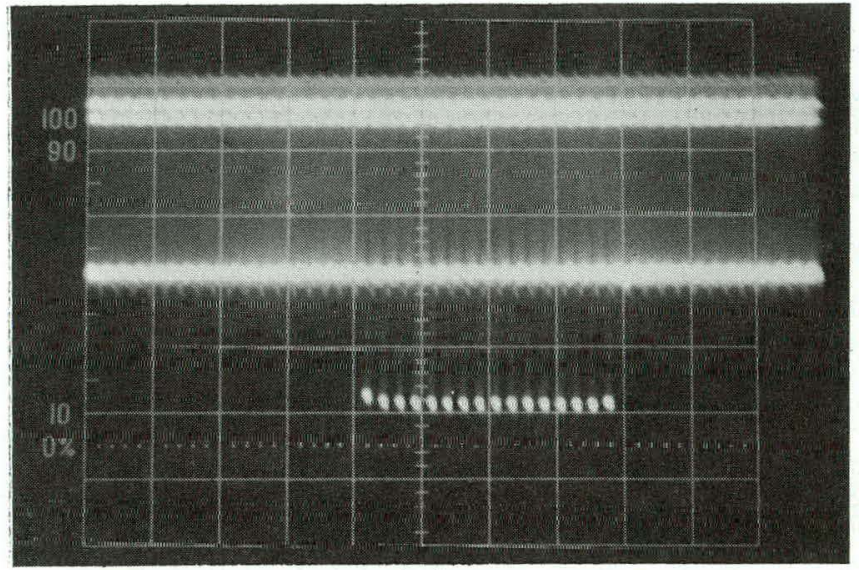

(a)

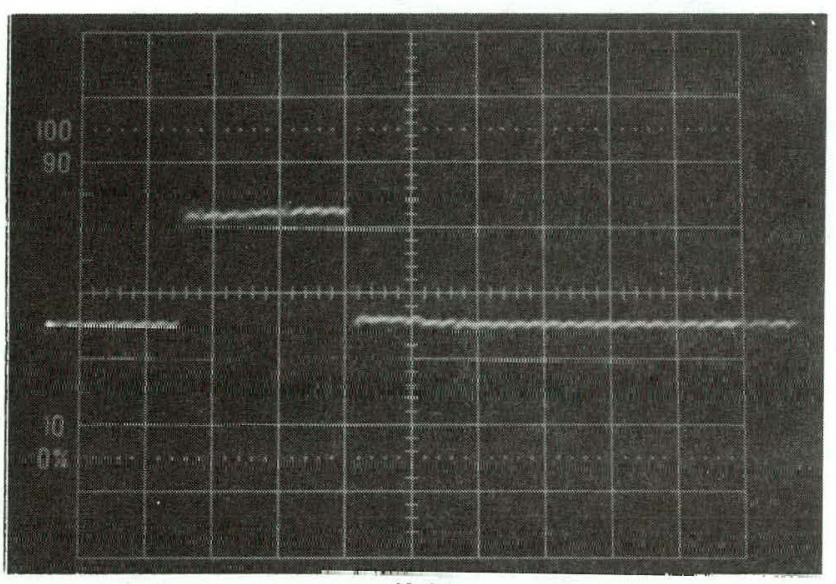

(b)

FIG. 5. (a) Typical pulse response of a single transfer register operated at a two-phase input clock frequency of $200 \mathrm{MHz}$ and a four-phase readout clock frequency of $200 \mathrm{kHz}$. Vertical scale: $100 \mathrm{mv} /$ division; horizontal scale: $100 \mu \mathrm{s} /$ division. (b) Input signal to LCCD. Vertical scale: $1 \mathrm{~V} /$ division; horizontal scale: 20 ns/division. 


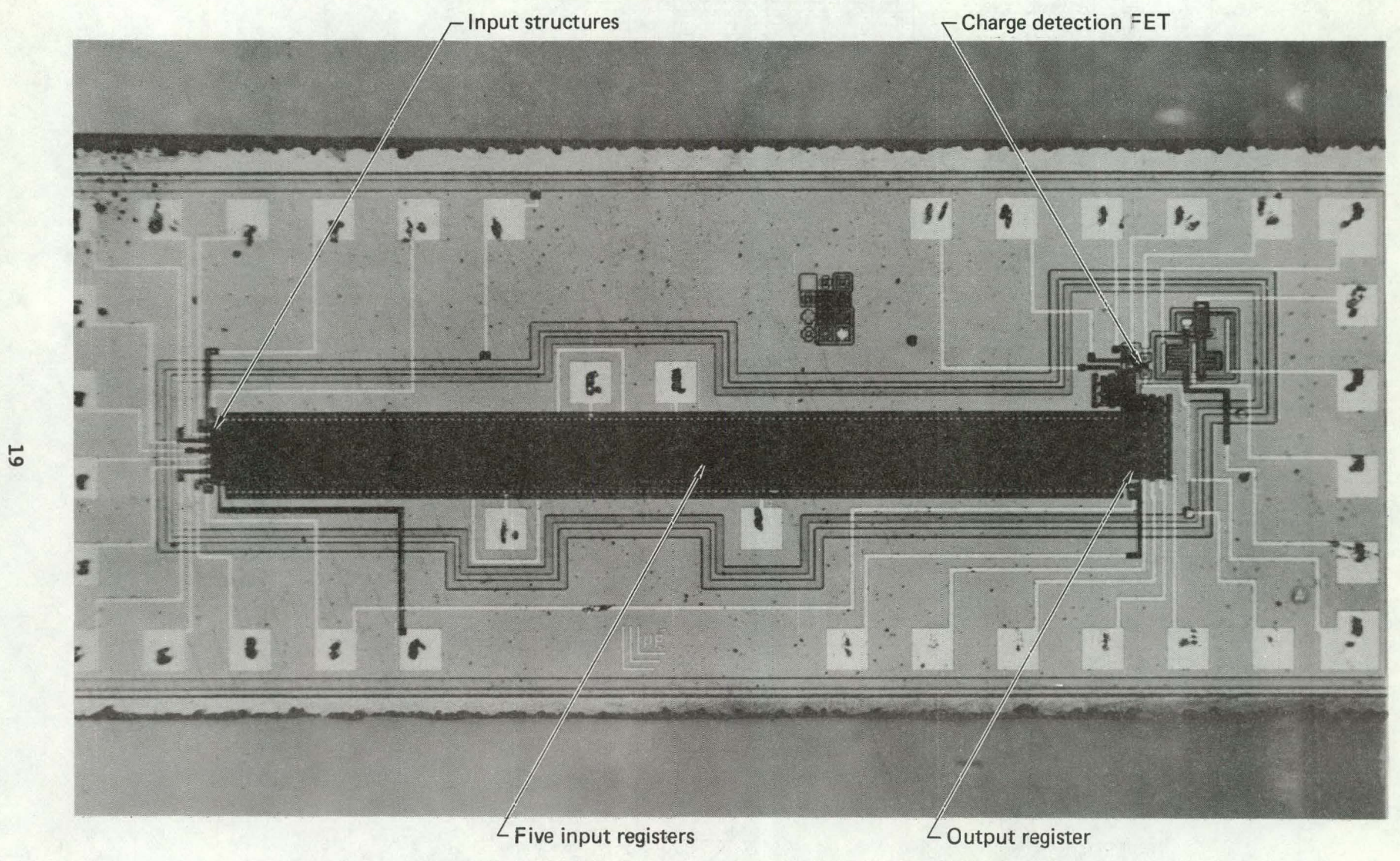

FIG. 6. Photomicrograph of the LCCD showing five identical input registers, each 132 stages long, and a multiplexing output register for driving the output charge detection FET. 


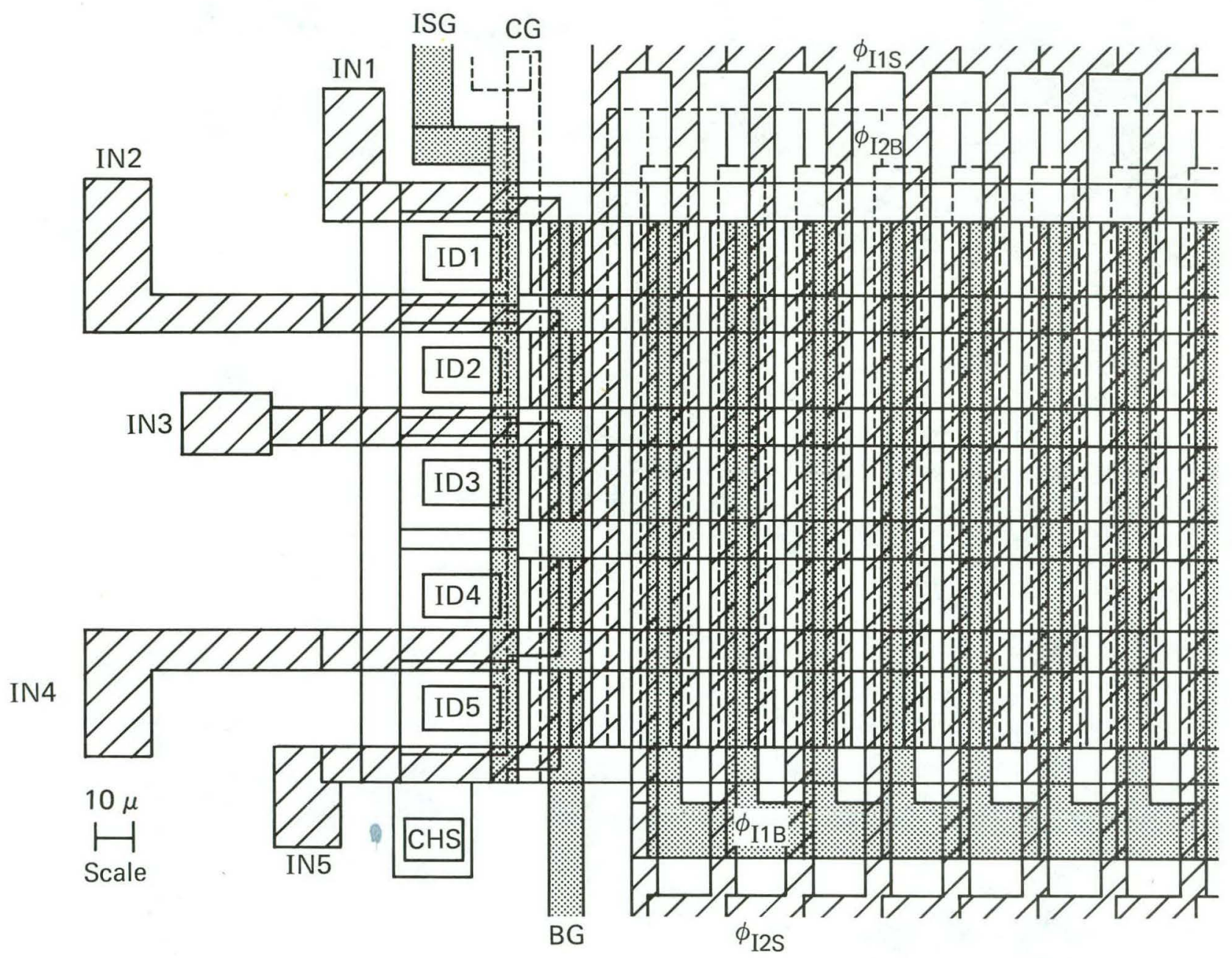

FIG. 7. Composite drawing of five input structures and input registers. 


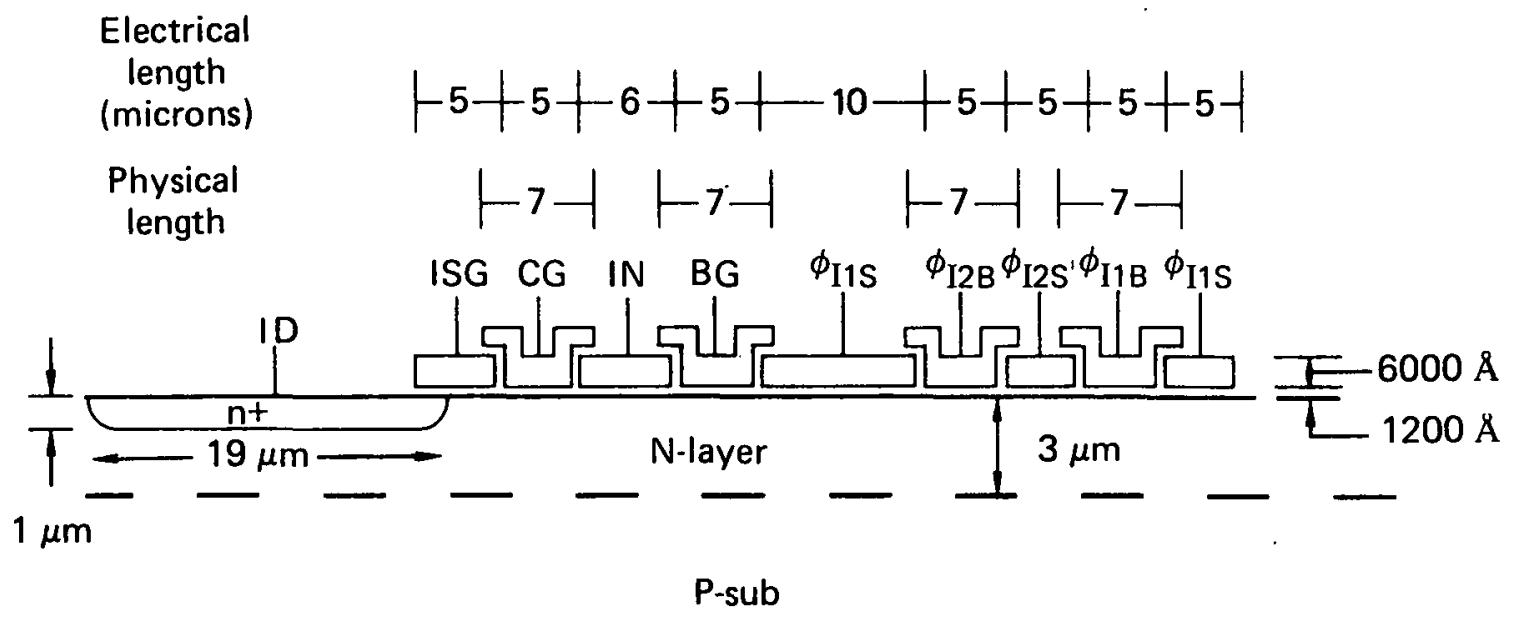

FIG. 8. The input structure and first stage of an input transfer register. The $1200 \AA$ dielectric between the transfer electrodes and the silicon surface consists of $800 \AA$ of silicon dioxide and $400 \AA$ of sillcon nitride. 


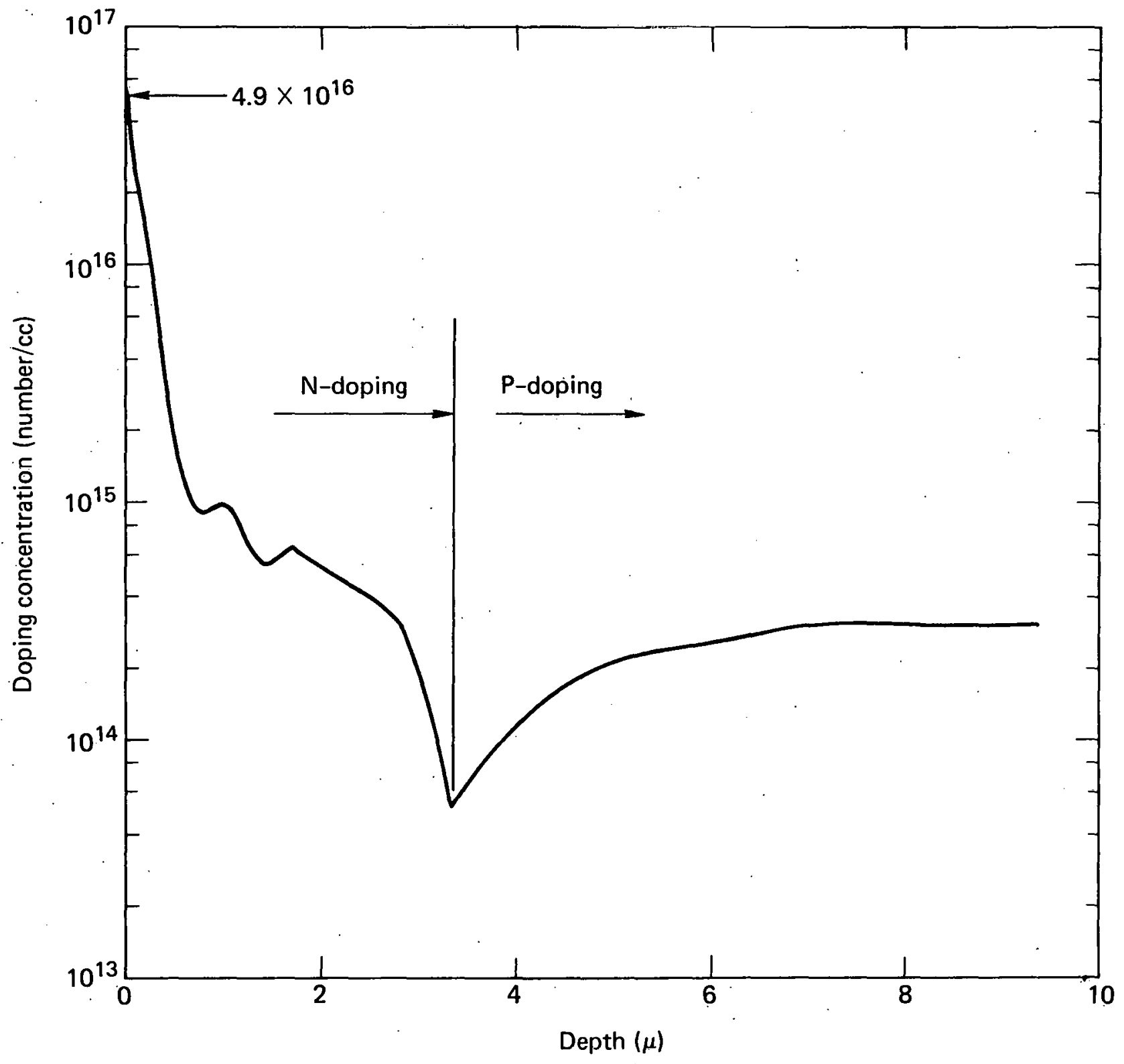

FIG. 9. Measured impurity profile for buried channels of LCCD. 


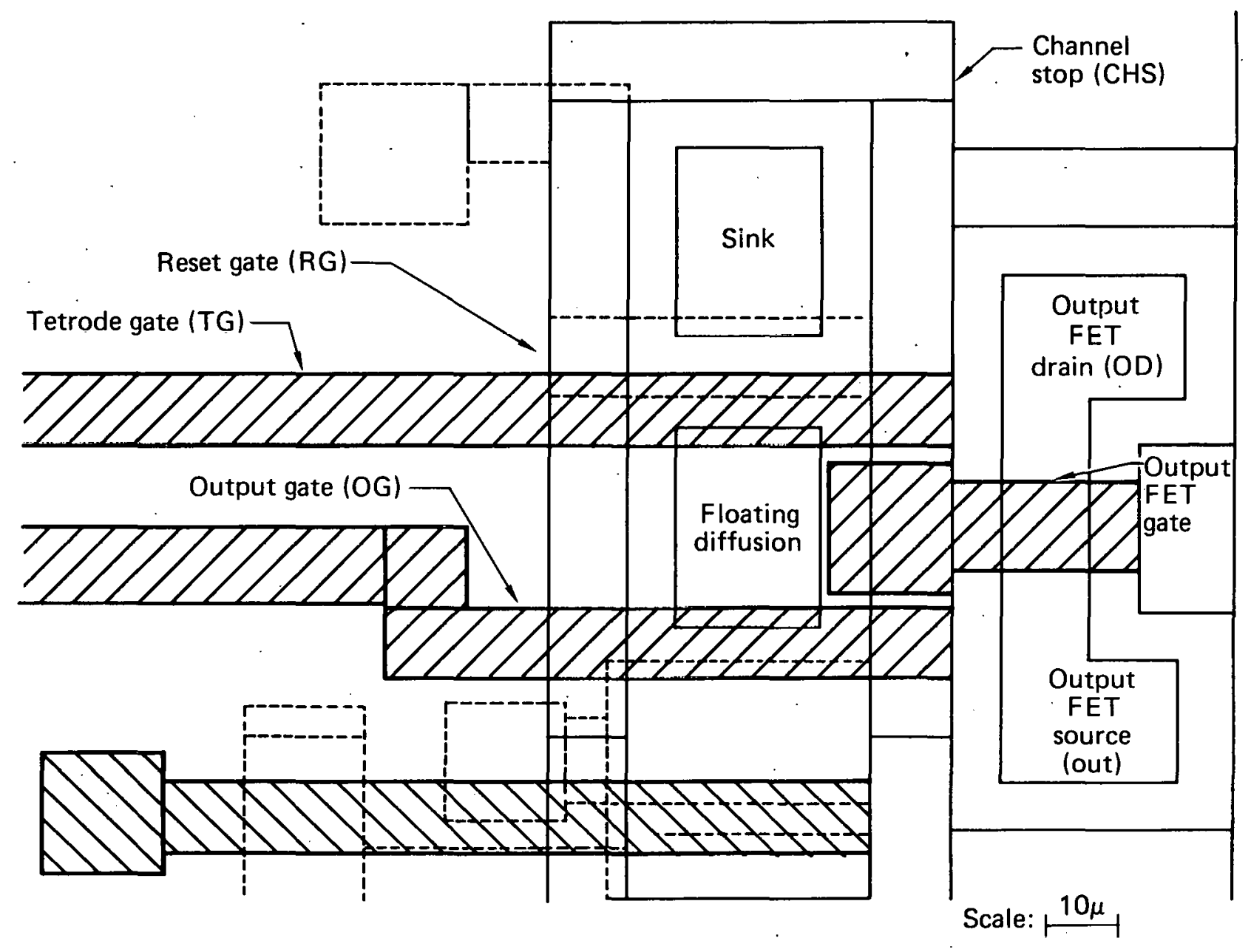

FIG. 10. Composite drawing of charge detection FET for the LCCD. 


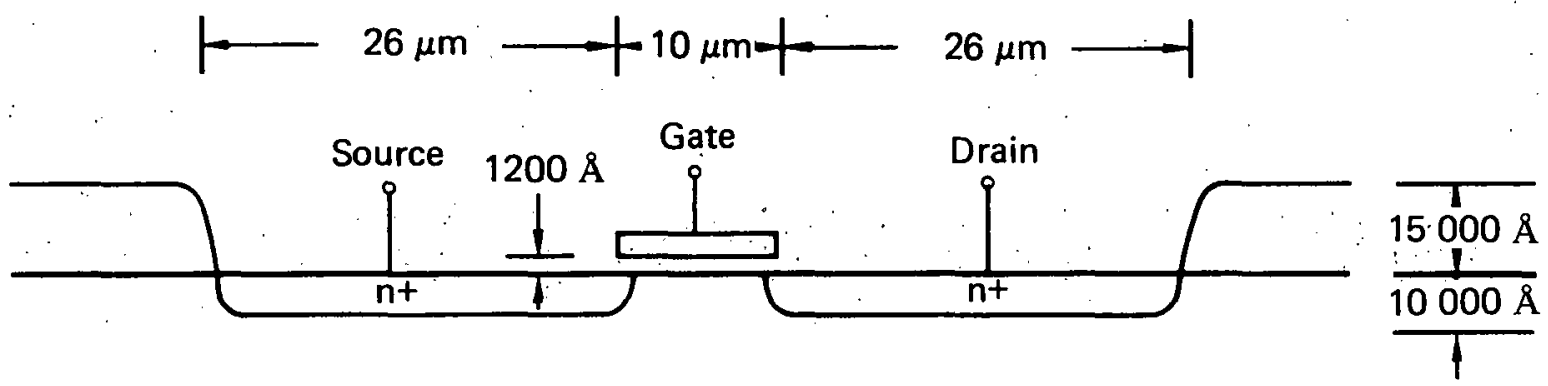

P-sub

FIG. 11. Cross sectional view of the charge detection FET. 


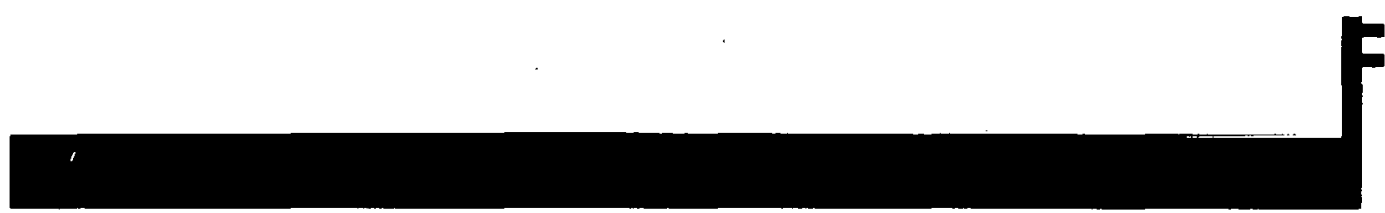

FIG. 12. Mask LCCD-1; N-Channel implant mask. 


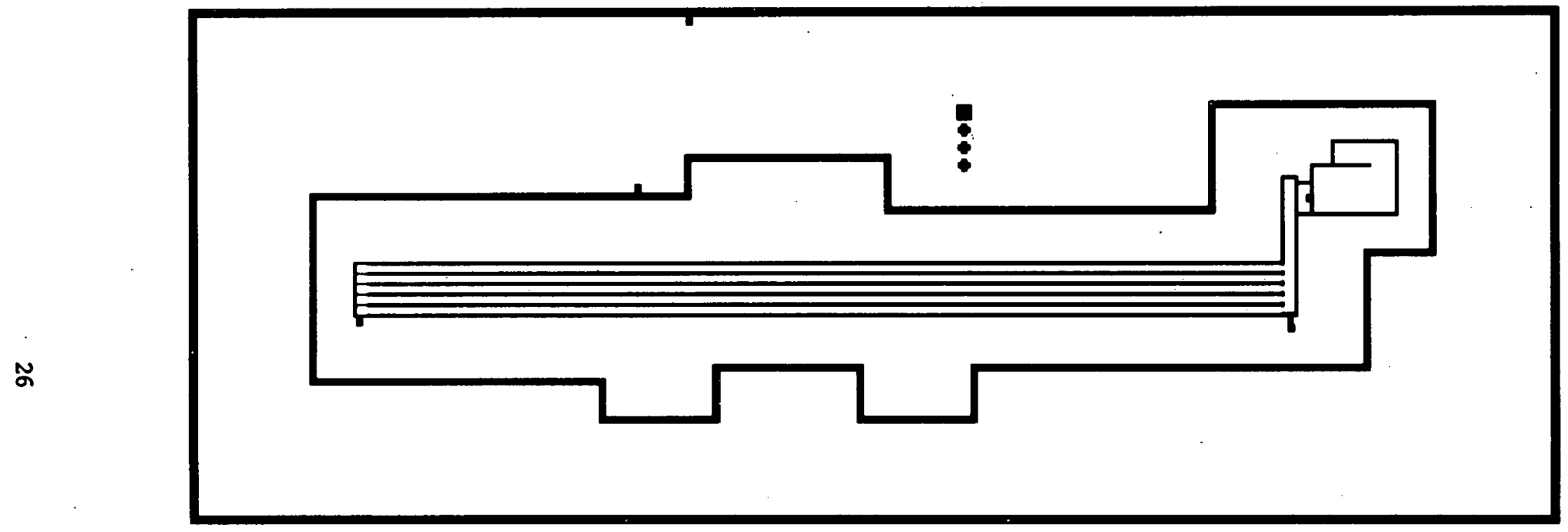

FIG. 13. Mask LCCD-2; Channel stop mask.

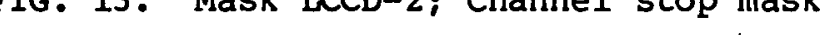




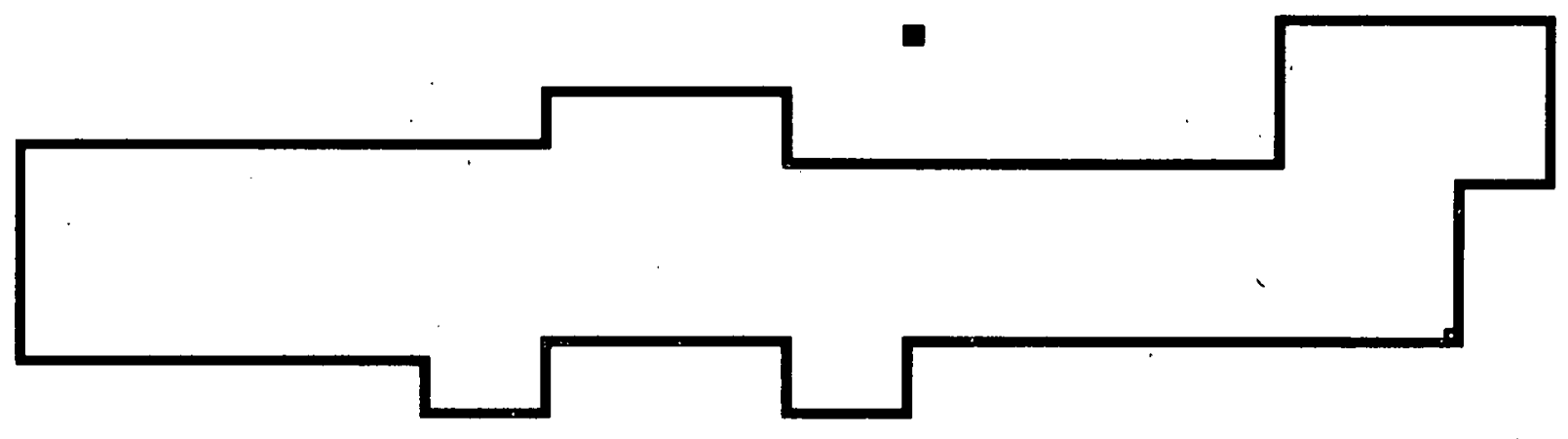

FIG. 14. Mask LCCD-3; N-Moat mask. 


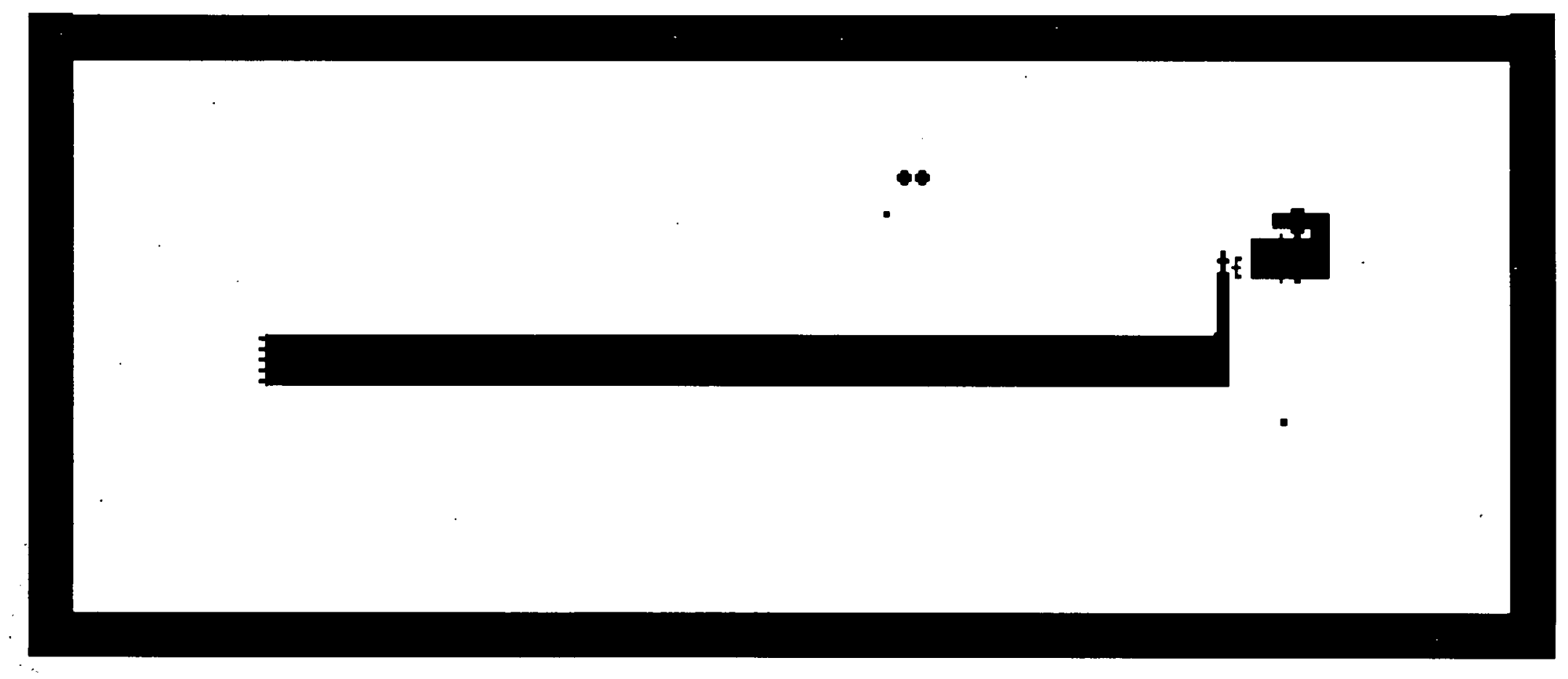

FIG. 15. Mask LCCD-4; Channel window mask. 


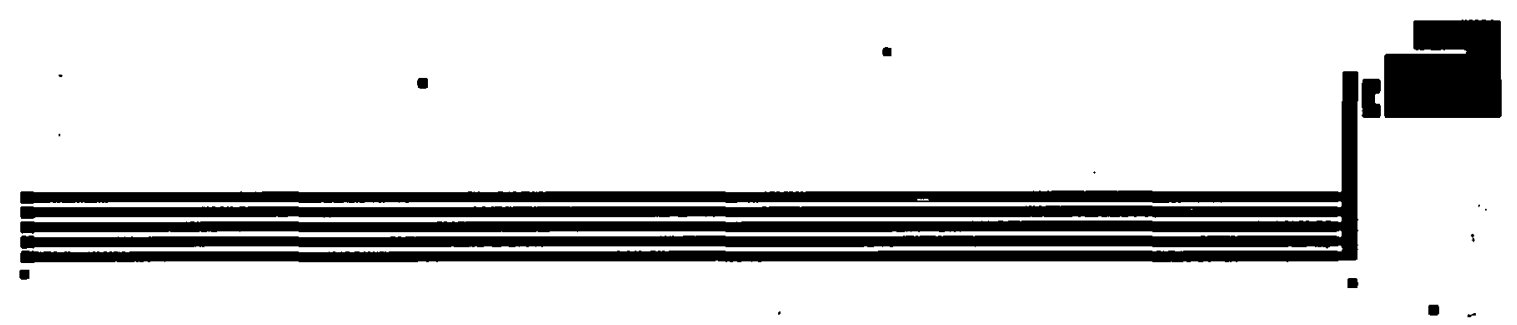

FIG. 16. Mask LCCD-5; Channel nitride mask. 


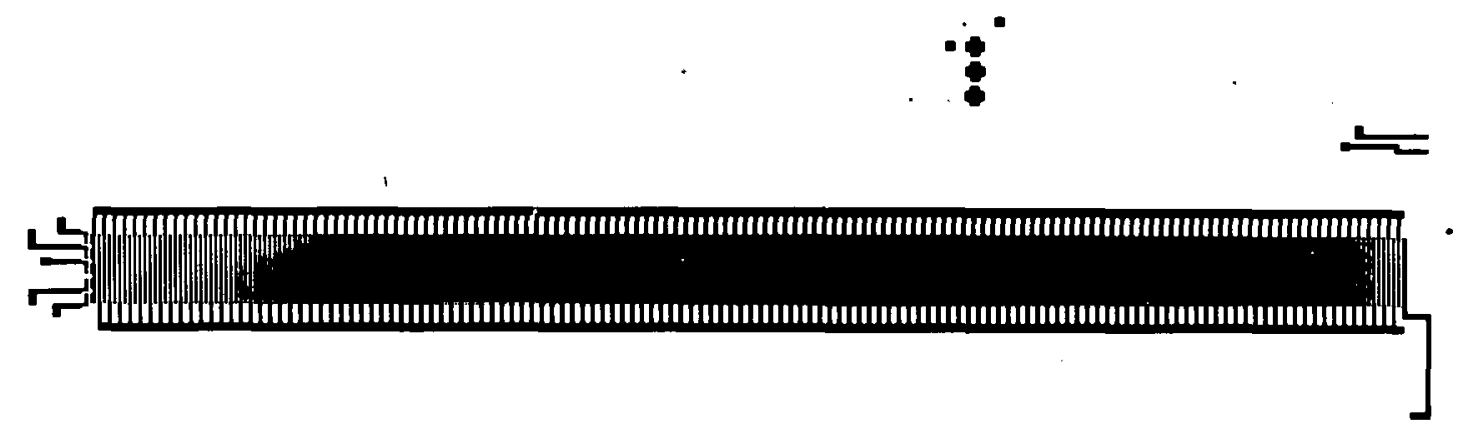

FIG. 17. Mask LCCD-6; First pölysilicon mask.

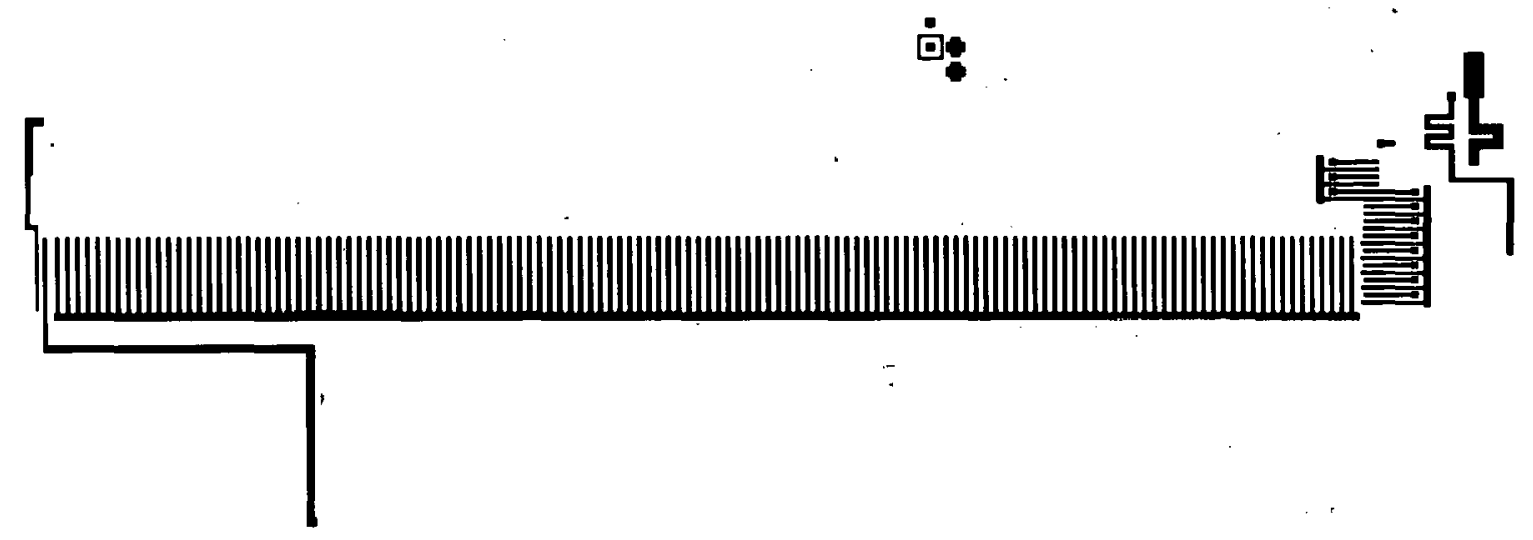

FIG. 18. Mask LCCD-7; Second polysilicon mask.

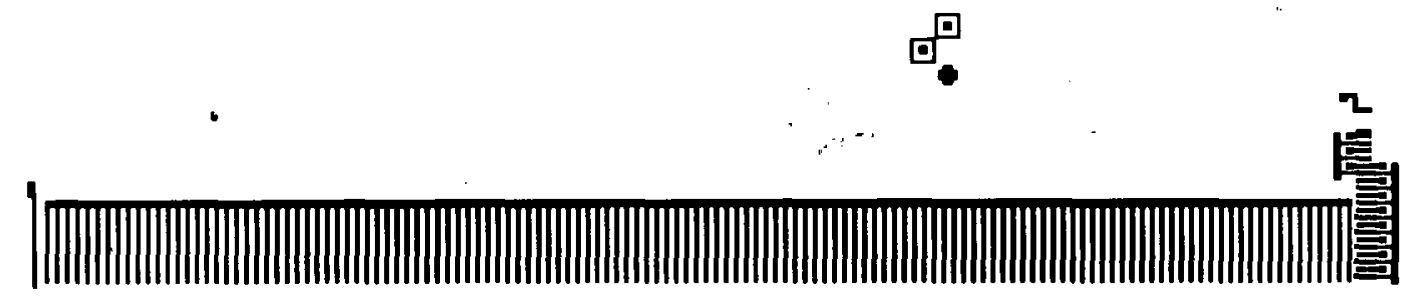

FIG. 19. Mask LCCD-10; Third polysilicon mask. 


\section{$\square$}

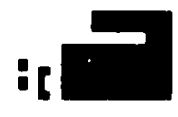

FIG. 20. Mask LCCD-11; N+ I/O diffusion mask. 


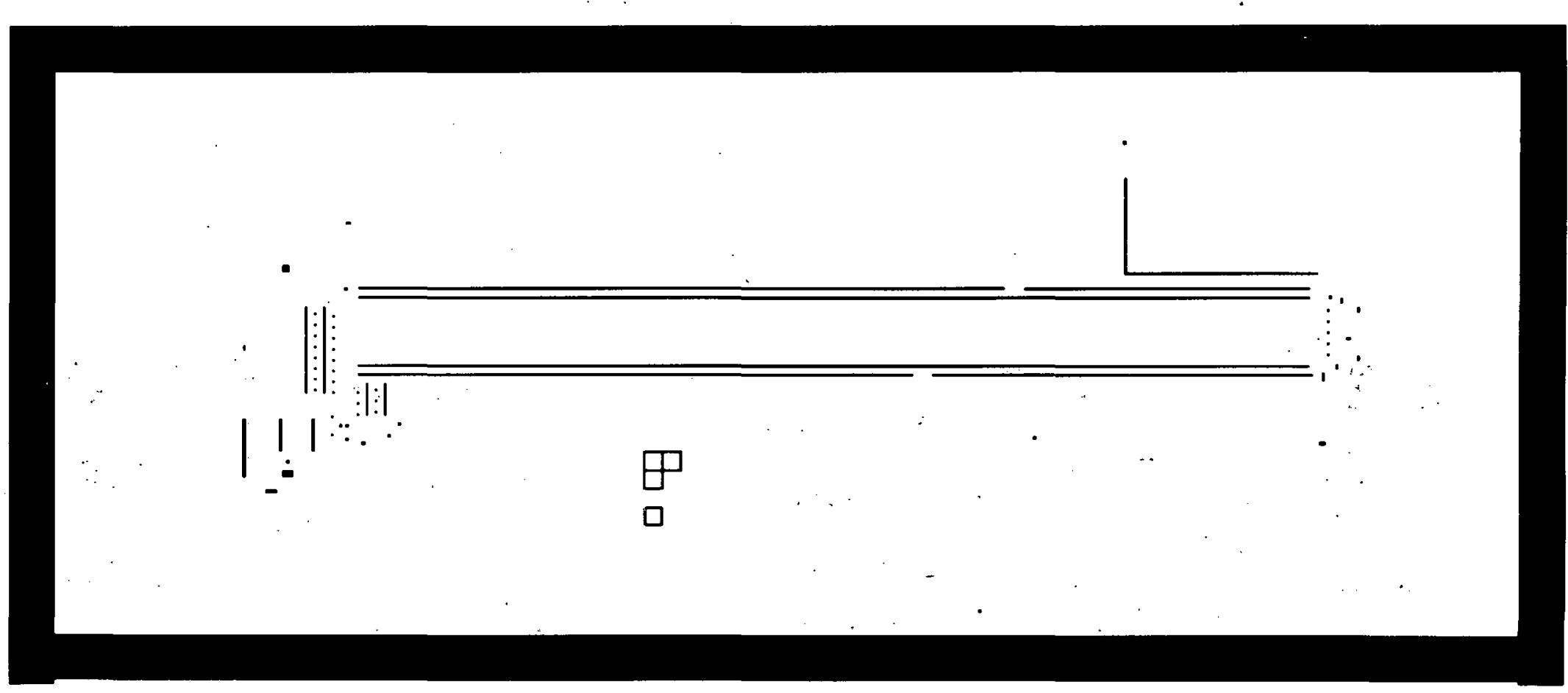

Fig. 21. Mask LCCD-12; Contact windows mask. 


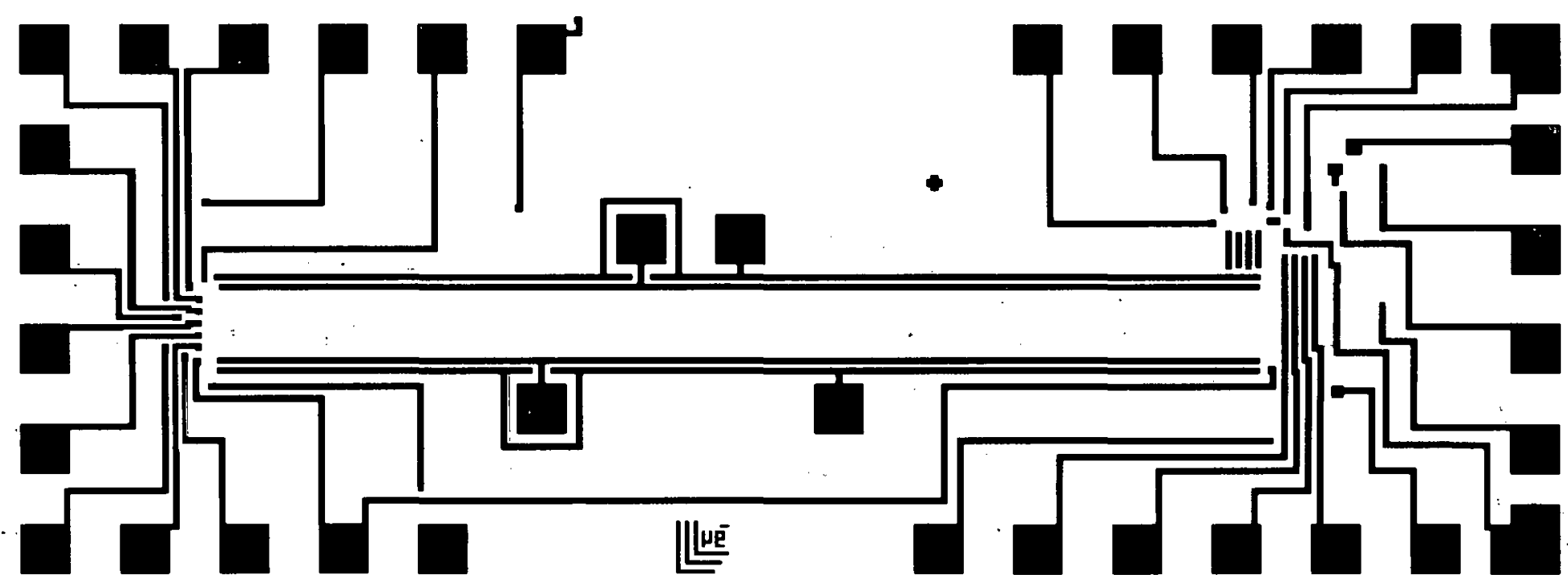

Fig. 22. Mask LCCD-13; Metal mask. 


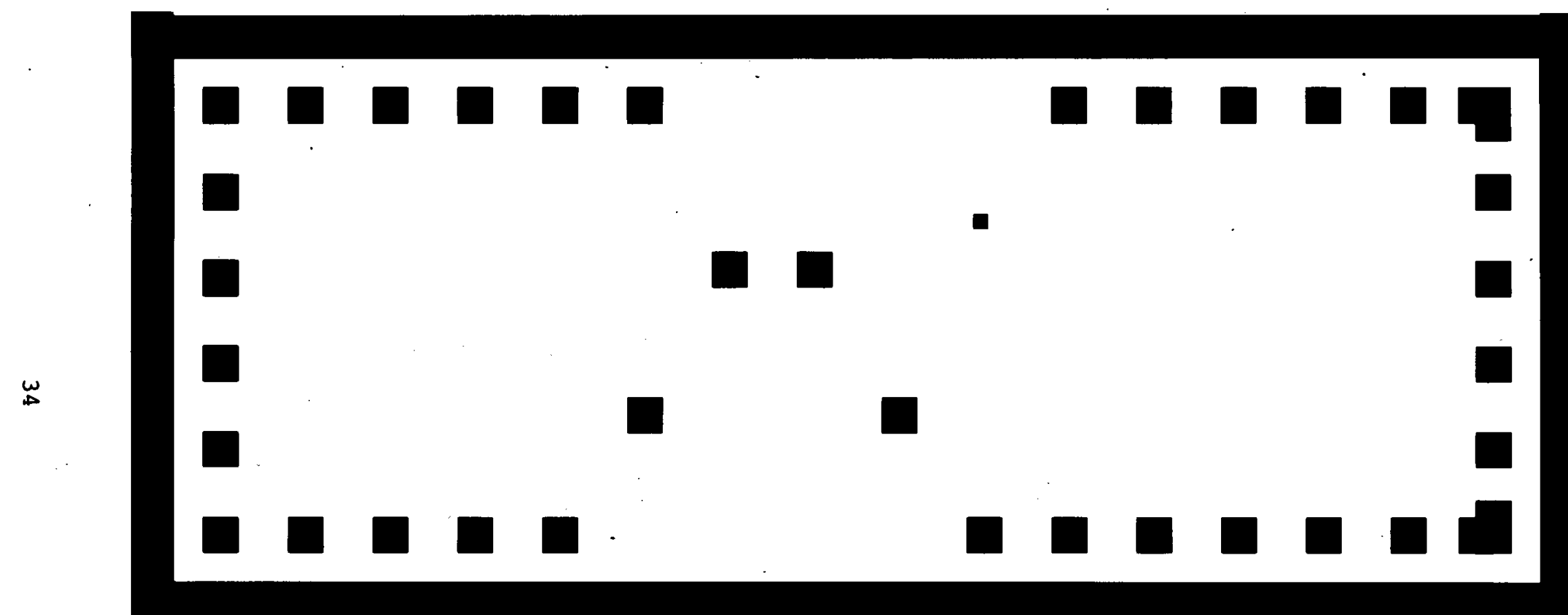

Fig. 23. Mask LCCD-14; Bond pad windows mask.

$\frac{5}{2}$
$?$
$\overrightarrow{0}$
$\stackrel{0}{\sigma}$ 


\section{DISCLAIMER}

This document was prepared as an account of work sponsored by an agency of the United States Government. Neither the United States Government nor the University of California nor any of their employees, makes any warranty, express or implied, or assumes any legal liability or responsibility for the accuracy, completeness, or usefulness of any information, apparatus, product, or process disclosed, or represents that its use would not infringe privately owned rights. Reference herein to any specific commercial products, process, or service by trade name, trademark, manufacturer, or otherwise, does not necessarily constitute or imply its endorsement, recommendation, or favoring by the United States Government or the University of California. The views and opinions of authors expressed herein do not necessarily state or reflect those of the United States Government thereof, and shall not be used for advertising or product endorsement purposes.

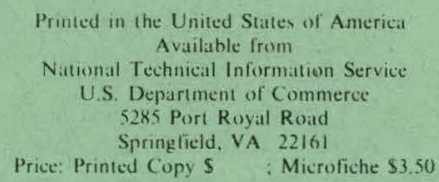

\begin{tabular}{|c|c|c|c|}
\hline Page Range & $\begin{array}{l}\text { Domestic } \\
\text { Price }\end{array}$ & Page Range & $\begin{array}{l}\text { Dumestic } \\
\text { Price }\end{array}$ \\
\hline $001-025$ & $\$ 5.00$ & $326-350$ & $\$ 18.00$ \\
\hline $026-050$ & 6.00 & $351-375$ & 19.00 \\
\hline $051-075$ & 7.00 & $376-400$ & 20.00 \\
\hline $076-100$ & 8.00 & $401-425$ & 21.00 \\
\hline $101-125$ & 9.00 & $426-450$ & 22.00 \\
\hline $126-150$ & 10.00 & $451-475$ & 23.00 \\
\hline $151-175$ & 11.00 & $476-500$ & 24.00 \\
\hline $176-200$ & 12.00 & $501-525$ & 25.00 \\
\hline $201-225$ & 13.00 & $526-550$ & 26.00 \\
\hline $226-250$ & 14.00 & $551-525$ & 27.00 \\
\hline $251-275$ & 15.00 & $526-550$ & 28.00 \\
\hline $276-300$ & 16.00 & 601 -up 1 & \\
\hline $301-325$ & 17.00 & & \\
\hline
\end{tabular}

${ }^{1}$ Add 2.00 for each additional 25 page increment from 601 pages up. 
